\title{
WHAT IS BIBLICAL MEDIA CRITICISM? A MEDIA- CRITICAL READING OF LUKE 9:51-56
}

\author{
JA Loubser \\ University of Zululand
}

\begin{abstract}
In Luke 9:51-56 Jesus rebukes his disciples for wishing revenge on the Samaritans for their lack of hospitality. The paper investigates the rich residual orality in the text and the probable transformations that occurred when this narrative was recorded and translated. A review of the available communications technology at the time of text production is followed by an examination of explicit and implicit data on orality and literacy. Some exciting communicative and social aspects of the text are explored. The paper concludes with a brief reflection on the relation between transmediation and the ethics of interpretation.
\end{abstract}

\section{Introduction}

It does not often happen that a new analytical tool becomes available to Biblical scholars. Although still largely unknown to the scholarly world such an instrument has been developed over the past century thanks to the work on different aspects of orality and literacy by Marcel Jousse, Eric Havelock, Walter Ong, Jan Vansina, Werner Kelber and Birger Gerhardsson, and many others. ${ }^{1}$ Studies on orality and literacy are increasingly coming into focus and will certainly gain momentum in the future. ${ }^{2}$

Such studies were usually called "orality studies" or "oral theory". As was to be expected it generated much controversy when applied to the world of the first century that already stood in a long tradition of literacy. Especially the seminal work of Gerhardsson, Memory and manuscript (1998, first published in 1961) explored the complex inter-relationship between orality and literacy in the rabinnic literature. From this it became clear that a study of the Biblical text from an orality-literacy point of view has to take a holistic view of the role of the oral and manuscript media employed in the production of texts. For this reason I am using the term Biblical "media criticism" to indicate such a holistic approach to the analysis of the media aspect of the text. For the purpose of such an analysis four elementary steps are required:

The available communication technologies at the time of text production need to be reviewed.

The text must then be examined for explicit and implicit data on orality and literacy and the type of media mix determined.

This should lead to a discussion of the communicative functions of the text.

Finally some hermeneutical functions of the text can explored.

1. Cf. Bibliography for references to these authors.

2. Two of the most recent studies in this field are from Sellin (1997) and Harvey (1998). Neither use the term "media criticism" though both works are focused on the influence of the oral and written media in the production of biblical texts. 
In the application of these steps to a specific text, viz. Lk 9:51-56, the value of this new method will be explored. Before moving on to the analysis, some theoretical considerations are briefly discussed. ${ }^{3}$

\section{Text and Medium}

In order to understand the relationship between texts and media we may observe how texts function within communication systems. At the risk of over-simplification we can describe a communication system as one in which a message is passed from a sender to a receiver. The message is presented to the receiver in textual form, i.e., messages are always encoded in texts. However, messages exhibit different textures that operate on many different levels. So, e.g., we find that ideas and concepts are organised in certain textures (ideological texture). We also find codes arranged in certain textures (e.g., grammatical-syntactic texture). One type of texture that is often overlooked, is the media texture of a message. Under media texture we understand those aspects of the message that relate to the specific properties of the media employed. An example of media texture is when a writer explicitly refers to the act of writing, providing the receiver additional information that may assist in the decoding of the text. Usually the media texture remains implicit in the text. A main function of media criticism is therefore to examine such implicit deployment of the media texture. Especially with ancient texts where the media of communication differ from those used by modern receivers, such an exercise can become a useful tool for interpretation.

The various textual aspects of the message - those relating to ideas, codes and media - are found to co-determine one another in a profound and complex way. In order to communicate a message, ideas are encoded by means of complex linguistic codes and expressed in a medium. In other words, the ideas we communicate and the codes through which they are organised are inherently influenced by the media they employ. Marshall McLuhan's famous overstatement that "The medium is the message," was intended to drive this point home. ${ }^{4}$ As an example of this we can consider the e-mail message as enabled by the electronic medium. Because it provides for a rapid exchange of written texts, it predisposes the author to address issues of immediate relevance (ideological texture) while also predisposing the author to use a style less formal than the conventional letter (literary texture).

The fact remains that a receiver's first acquaintance with a text is mediated through his or her competence to perceive, assess and interpret its physical properties (i.e., its media aspect). When, e.g., opening an ancient codex the very first action of an interpreter is to observe ink marks on parchment. What seems to be an obvious, self-explanatory exercise can become quite a challenge when the perception of the physical aspect and its properties is inadequate, e.g., when a tone-deaf person listens to a symphony. This even becomes more of a challenge when assessing the influence of the media properties on the shaping and organising of the ideas in a document. The diagrams below are intended to illustrate the argument thus far.

3. This is the subject of a forthcoming monograph by the author "Orality, Manuscript Culture and Biblical Media Criticism", including a revision of some articles by the author (1986, 1993, 1995, 1996).

4. For his basic thought, see McLuhan 1994, 1999. 

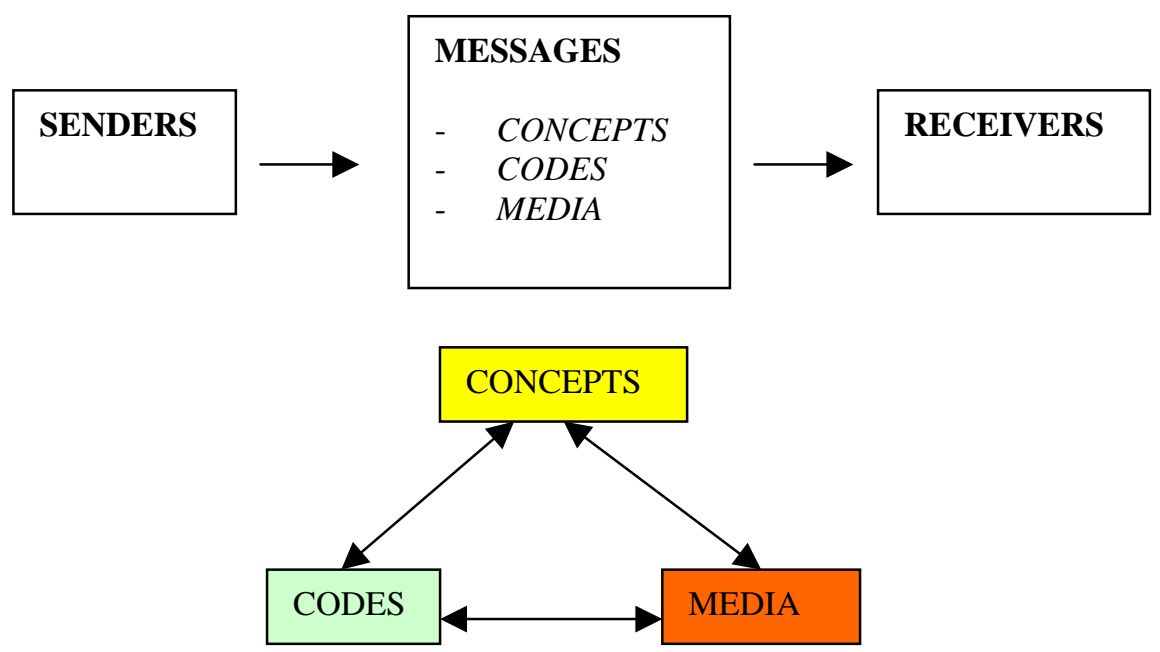

Because we have to deal with co-determining textures it is clear that a study of any one of the aspects of a message inevitably leads us to the other. The case of rhetorical criticism may serve as an example. The discipline began with a study of certain codes (namely those employed by the sender-speaker in order to persuade an audience) but has presently branched out to cover the so-called "rhetorical situation". The sub-discipline socio-rhetorical analysis, as developed by Vernon Robbins, was born out of the awareness that analysis needs to consider more than merely the rhetorical codes in the text. ${ }^{5}$

The question now remains as to how an awareness of media interaction with "codes" and "concepts" can serve our interpretation of the Bible.

In the case of the NT our first access to the message, is via a "frozen" or "cold" medium: manuscripts written in ink on parchment or papyrus. Everything that we extract from the NT had to be accessed through that medium. Every idea that was encoded and committed to writing had to comply with the limitations of this medium. As we shall see in the following paragraph, the manuscript was not the only medium that was used in Luke's world.

\section{Communication technologies available to Luke}

According to the broad scholarly consensus the Gospel of Luke was written some time before $150 \mathrm{CE}$, which places it shortly before the shift from an intermediate to a high manuscript culture which occurred at that date in the Roman Empire. ${ }^{6}$

In interpreting the media situation in the time of the NT we need to take note of the following: ${ }^{7}$

Different strata of society appropriated new media technologies at different times and it sometimes took centuries for new developments to be appropriated by the masses. By the

5. Cf. Robbins 1996 which contains a comprehensive statement of his mature theory.

6. This is rough estimate for the shift from intermediate to high manuscript culture. The date is based on the assumed emergence of the codex at that time, and also the development of sophisticated literary exercises of Marcion. This is also the time at which "libraries" came into a much wider public use than previously.

7. The following points are comprehensively illustrated in Thomas (1992). 
first century almost everyone could figure out the letters of the Greek phonetic alphabet, but those who could write more than their names were few.

There are no radical breaks in the patterns of communication, or consciousness, between the successive phases or in the different modes that co-existed in the first century, though smaller shifts and different emphases can be observed. Only when comparisons over longer stretches of time are made do we find clear shifts.

In all the media modes that succeeded the oral phase, the conventions of oral communication still dominated the text (e.g., the tendency to regard the spoken word as of primary importance, assuming a high degree of rote memory in the learning process, and with the basic literary forms closely resembling the preceding oral forms). Manuscript writing much resembled the spoken word: the Greek phonetic alphabet was used in one continuous stream of letters without and spaces or breaks; emphases in the text had to be indicated by effective stylistic devices like foregroundings, chiasms, ring compositions, etc. Manuscripts also imposed limits on the text: papyrus was expensive which demanded short letters and documents.

If these assumptions are correct, it means that we can expect to find four modes of orality/literacy existing alongside one another in the Lukan world:

- Oral communication. Walter Ong describes this type of communication in primary oral discourses as follows: Expressions are additive rather than subordinative, aggregative rather than syntactic. The style is characterised by redundancies ("copiousness"). Thought is conceptualised and expressed with close reference to the human lifeworld. It is concrete and situational rather than abstract. Expressions are agonistically toned, but also participatory and empathetic. There is a tendency to be conservative and homeostatic (Ong 1982a: 31-77).

In the first century Mediterranean world, however, we do not find "pure" orality, but a kind of reconstituted orality, as it developed in the wake of newer communications technologies and economic conditions. By this time orality would have lost some of its memory functions, though it still dominated communication conventions.

- Scribal practices (as adapted to manuscript culture). Scribes have become part of the broad cultural life, serving intellectual and personal needs. Centuries before, scribes were only employed by kings and religious bodies and served the maintenance of power.

- Primary manuscript culture, signified by the public performance of authoritative documents to assist memory (e.g. the reading/performing of the Hebrew Bible in the synagogues; the performance of the Greek tragedies). This type of media usage originated around $500 \mathrm{BCE}$.

- Intermediate manuscript culture, signified by a high level of orally transmitted reflection on/interpretation of written manuscripts. In this media mix, that became popular during the Hellenistic era, we find elaborate oral commentaries on texts that exist in manuscript form, and these orally transmitted commentaries begin to resemble the features of the written word, e.g., they are transmitted with almost the same degree of accuracy. (In the subsequent phase, we find this augmented and eventually replaced by an intertextuality between manuscripts. $)^{8}$

We shall now take up the challenge to identify these modes as reflected in the studied text.

8. Intermediate manuscript culture is sometimes also called "Rhetorical culture" (cf. Robbins 1995:75ff). 


\section{Textual data on orality and literacy}

When examining the textual data that imply media usage in Luke 9:51-65 we can distinguish two levels in the text. First there is the communication by Luke to his audience and secondly, imbedded in the narrative, we find a report on an oral exchange between Jesus and his disciples.

Now let us examine the text first. How Luke employed his medium can best be observed by a comparison with subsequent translations that sought to communicate with people in media cultures differing from that of Luke.

\begin{tabular}{|c|c|c|c|}
\hline $\mathbf{N}-\mathbf{A}$ & VULGATE & RSV & NIV \\
\hline 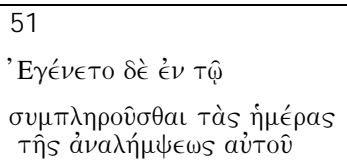 & $\begin{array}{l}\text { factum est autem dum } \\
\text { conplerentur dies } \\
\text { adsumptionis eius }\end{array}$ & $\begin{array}{l}\text { And it came to pass, when } \\
\text { the time was come that he } \\
\text { should be received up, }\end{array}$ & $\begin{array}{l}\text { As the time } \\
\text { approached for him to } \\
\text { be taken up to heaven, }\end{array}$ \\
\hline 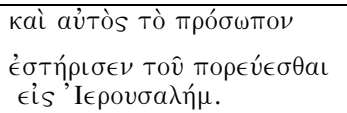 & $\begin{array}{l}\text { et ipse faciem suam firmavit } \\
\text { ut iret Hierusalem }\end{array}$ & $\begin{array}{l}\text { he steadfastly set his face } \\
\text { to go to Jerusalem, }\end{array}$ & $\begin{array}{l}\text { Jesus resolutely set out } \\
\text { for Jerusalem. }\end{array}$ \\
\hline 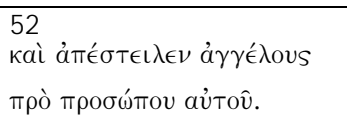 & $\begin{array}{l}\text { et misit nuntios ante } \\
\text { conspectum suum }\end{array}$ & $\begin{array}{l}\text { And sent messengers } \\
\text { before his face: }\end{array}$ & $\begin{array}{l}\text { And he sent } \\
\text { messengers on ahead, }\end{array}$ \\
\hline 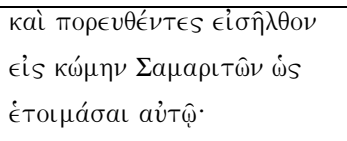 & $\begin{array}{l}\text { et euntes intraverunt in } \\
\text { civitatem Samaritanorum ut } \\
\text { pararent illi }\end{array}$ & $\begin{array}{l}\text { and they went, and entered } \\
\text { into a village of the } \\
\text { Samaritans, to make ready } \\
\text { for him. }\end{array}$ & $\begin{array}{l}\text { who went into a } \\
\text { Samaritan village to } \\
\text { get things ready for } \\
\text { him; . }\end{array}$ \\
\hline 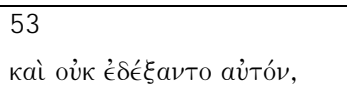 & et non receperunt eum & $\begin{array}{l}\text { And they did not receive } \\
\text { him, }\end{array}$ & $\begin{array}{l}\text { but the people there } \\
\text { did not welcome him, }\end{array}$ \\
\hline 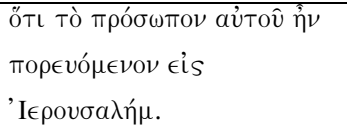 & $\begin{array}{l}\text { quia facies eius erat euntis } \\
\text { Hierusalem }\end{array}$ & $\begin{array}{l}\text { because his face was as } \\
\text { though he would go to } \\
\text { Jerusalem. }\end{array}$ & $\begin{array}{l}\text { because he was } \\
\text { heading for Jerusalem. }\end{array}$ \\
\hline 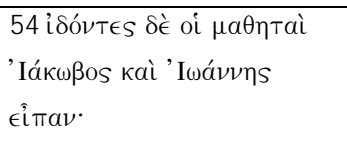 & $\begin{array}{l}\text { cum vidissent autem discipuli } \\
\text { eius Iacobus et Iohannes } \\
\text { dixerunt }\end{array}$ & $\begin{array}{l}\text { And when his disciples } \\
\text { James and John saw this, } \\
\text { they said, }\end{array}$ & $\begin{array}{l}\text { When the disciples } \\
\text { James and John saw } \\
\text { this, they asked, }\end{array}$ \\
\hline 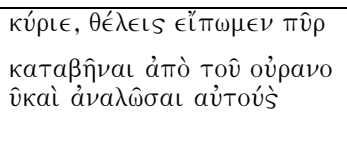 & $\begin{array}{l}\text { Domine vis dicimus ut ignis } \\
\text { descendat de caelo et } \\
\text { consumat illos }\end{array}$ & $\begin{array}{l}\text { Lord, wilt thou that we } \\
\text { command fire to come } \\
\text { down from heaven, and } \\
\text { consume them, }\left[{ }^{*}\right]\end{array}$ & $\begin{array}{l}\text { "Lord, do you want us } \\
\text { to call fire down } \\
\text { from heaven to destroy } \\
\text { them?" }\end{array}$ \\
\hline 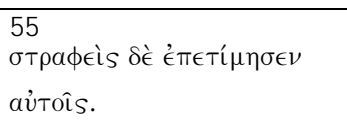 & et conversus increpavit illos & $\begin{array}{l}\text { But he turned, and } \\
\text { rebuked them }[* *]\end{array}$ & $\begin{array}{l}\text { But Jesus turned and } \\
\text { rebuked them, }\end{array}$ \\
\hline
\end{tabular}

The RSV includes two later glosses: at * is added "even as Elias did?", and at ** "and said, Ye know not what manner of spirit ye are of. 56 For the Son of man is not come to destroy men's lives, but to save them." 


\section{Luke's medium of communication}

Unlike the Johannine authors Luke did not consciously reflect on his medium, though he mentions in 1:1-4 that he made use of eyewitness accounts and that he wrote them down in an orderly manner. We thus have primary evidence that the Lukan Gospel consists of the literary reworking of oral narratives. This poses the question as to how much the oral texts were transformed by the process of organising them into an orderly account and committing them to manuscript.

\section{Formulaic, rhythmic, paratactic style}

Luke's style, as reflected in this section is that of a religious narrative with an underlying oral substratum. There is a narrative rhythm that runs through the whole episode. Almost every new phrase is introduced by either de (3 times) or kai (5 times). A comparison with the two English translations shows how difficult the translators found it to maintain this (Hebraic, but also oral) paratactic style. The RSV modifies it in 51b and in 55. The NIV uses "and" only twice, and "but" only twice. It is clear that the modern translators, reconstructing the text in terms of a new medium-i.e., that of clear prose-transformed the oral conventions of the Greek text, whereas the Vulgate sought to maintain it.

This "oral style" is further reflected by the abundance of formulaic expressions and repetitions that are somewhat difficult to gather from the translations. Examples are:

In the first 3 verses, the "face" of Jesus (to prosopon) is mentioned thrice. Whereas the RSV keeps on translating "face", the word is altogether omitted by the NIV. Even the Vulgate found this repetition cumbersome and alternates the word for face (facies) with conspectum in verse 52 .

Also the Lukan word for village, kome, is alternatively translated with civis and castellum This is a clear sign that the Vulgate already operated in a high manuscript culture, in distinction from Luke. The Vulgate, in other words, no longer regarded the manuscript of Luke as just an aid to recitation from memory, but as a literary document. This tendency for stylistic variation can already be observed in some later versions of the Greek text, who use polis instead of kome in vs. 52 .

The only place in the text where the rhythmic narration is accelerated is with the word "saw" (idontes) in vs. 54. Here the natural rhythm of the narration in the previous series of expressions is halted by the foregrounding of the verb. It signals a change in focus. However, in the English translations this quickening of the pace and the heightening of the tension is completely missed because of the protracted phrase used in translation, "When the disciples James and John saw this."

All types of speech, even in written form, exhibit some internal rhythm. Nevertheless, oral narration is noted for its incessant use of heavy rhythms and formulaic expressions that serve as mnemotechnical devices (see Ong 1982a:34-35). Luke obviously did not regard himself as a "writer," but rather as representing oral narratives.

\section{Redundancies and reductions}

Redundancies in Luke also reflect an oral substratum, ${ }^{9}$ as, e.g., reflected in the RSV which literally follows the Greek text.

9. For the effects of redundancy see Ong, 1982a:39-40. 
The expression "and it came to pass" is superfluous, but functions as a typical introductory formula, enabling the audience to adjust to a new frame;

The expression "set his face" is also redundant, but is a typical Hebraism (2 Sam 17:11) emphasising Jesus' resolution of going to Jerusalem;

The repetition of the word "Jerusalem" is not necessary when communicating in a literary mode, but serves here to symbolically emphasise the place of destiny;

"And they went and entered" is another expression retarding the orally narrated time;

"But he turned and rebuked" is another such expansive (copious) phrase.

In the above examples we have seen how narrated time is protracted to create emphasis and to heighten tension; Jesus' resolve to proceed to Jerusalem is emphasised by repetition. But there are also contractions to signify a narrative climax, e.g., the phrase beginning with "saw" (vs. 54). Other reductions are the two disciples apparently speaking at the same time, saying the same thing. The same can be said of the use of the concise use of the word thelei instead of the classical boulomai ina; and the cryptic reference to "a Samaritan village."

Such redundancies and reductions can also be literary devices, but in oral narrative they appear incessantly. In oral speech words are forgotten once they have been spoken rendering it impossible to "back-track." Therefore important data have to be repeated. On the other hand, a narrator tends to eliminate those details that do not directly interest and involve the audience. The redundancies and reductions in this passage thus point to an oral substratum that has been suppressed by the various translations to different degrees. ${ }^{10}$

Without arguing the oral poetics of Luke further, it is clear that his narrative follows basic oral conventions. What he (or his scribe) wrote down was not an individual literary composition, but rather the scribal recording of a tradition that had been orally shaped through innumerable repetitions from memory. Further, it was intended to be recited/performed aloud to a live audience.

\section{Communication as reflected in the text}

Apart from the Lukan communication data as reflected in the text, the reported episode also implies communication in the oral medium. In the description of Jesus and his disciples, we observe the ethic of a wandering oral teacher. Let us examine some of the indicators.

\section{Practices of an oral teacher}

In the episode we have a wandering teacher, now firmly bent on reaching his destination, Jerusalem. According to the convention of an oral rabbi, his disciples were to learn from his every move. ${ }^{11}$ They had to memorise and relate it. They had to take him in like food and digest him; they had to become him. ${ }^{12}$ They were to be his authorised witnesses. This also indicates the explicit purpose of Luke: he wanted to promote such an idea of discipleship.

The master sent his messengers ahead with an oral message. According to the convention, we can assume that this was an authorised mission and the preparations they had to make were not just for board and lodging. To be received implied that the host should also enter

10. For a more detailed motivation of the statements in this paragraph, see Ong 1982:38-39.

11. Ong 1982a:67 explains that oral memory involves a high "somatic" content. Gestures serve as mnemonical aids.

12. This idea is explained at length by Jousse, 1997:447ff. 
into dialogue with the wandering teacher and honour the social conventions of oriental hospitality hammered out over many centuries.

\section{Hearing and seeing}

When the messengers returned with negative news, John and James "saw" what had happened. Why the word "saw" when they obviously had "heard"? One explanation is that the word idontes can be a synonym for "hear" or "note." But the fact that the word "saw" is foregrounded by the change in rhythm at this stage renders it more likely that it is a hint to the Lukan audience, subtly suggesting that they had to visualise the narrated episode. This is also typical of oral narration: the elimination of historical distance between narrative time and narrated time. The visual aspect also indirectly takes further the emphasised reference to Jesus' "face." This is an indication of the focalising in the text: Jesus looks at Jerusalem; the disciples look at him; eventually he turns around and looks at them.

The word "see" therefore points to the live dramatic performance of the text by the readerperformer. The audience had to hear, feel and see in order to become participants. The manuscript only functioned as a synecdoche, as a partial record of a much richer live performance of the narrative by the evangelist.

\section{Oral intertext}

Another "oral" feature of the text, is the nature of the question of the disciples (vs. 54b). It is either a recontextualisation of 2 Kings 1:10.12 or an echo of it, just evoking the memory of that text. ${ }^{13}$ It is, though, not a reference to the written documents of the sacred tradition, but rather to its memorised form. An indication of this is that in the LXX katafagein instead of the analosai of the Lukan text is used. This report depicts Jesus and the disciples as part of an intermediate manuscript culture. In primary manuscript culture manuscripts are read to refresh memory, with the memorised version being the "real" one. Intermediate manuscript culture maintains this practice, but develops a sophisticated interaction between the memorised tradition and the reflection on it. It is obvious that Jesus and his disciples conducted such a sophisticated reflection of the sacred tradition that was indirectly mediated by manuscript writing.

The associative meanings invoked by the theme of "fire from heaven" also draw on an (oral) tradition which has accumulated many associations over time. Fire was perceived to be the gift and scourge of the gods; a primal force in creation, the cause of apocalyptic fear. Its value was ambiguous; a sign of literal judgement recalling the punishment of Sodom (Luk 17:29). Fire is also associated with Elijah (Luk 1:17; 3:16-17) to be read esp. with ref. to the mentioning of Elijah in 9:8,19 and 30) and later in Luke is identified with the Spirit and seen as the fire of purification (Luk 12:49).

\section{Gestures}

Pointing also to the live performance of the oral narrative are the reported gestures in the text. We have noted the stylised emphasis on Jesus who "set his face" toward Jerusalem (the first step of his exodus). This paints the vivid picture of a rabbi steadfastly walking ahead to his place of destiny, with his disciples following behind in single file. The most striking gesture of the whole episode, illustrating its climax and point, is when Jesus "turns around" and rebukes his disciples. This interruption is reported in counterpoint to Jesus' movement forward, suggested by the steady rhythm of the opening phrases. 
This heavy dependence on stylised gestures is a clear sign of oral conventions reflected in the manuscript.

\section{Power words}

A last instance of oral texture we can note is the power implied in the word "rebuke." In oral environments words are perceived to be powerful in a way that is difficult for modern people to imagine. Words are perceived to be dynamic, creative events and not the loose standing semantic markers we assume they are. This view is reflected in the curse and blessing formulae of the OT, but also in the very meaning of the "word" (dabar) of the gospel. The setting within which they are used here, is that of an oral duel, typical of the agonistic tendencies of oral cultures. When rebuked by Jesus a fig tree withers and dies (Mark 11:14 reflected in Luk.13:7). The disciples in the episode wished to exercise that same power, "Lord, do you wish us to say...?" It is obvious that the rebuke was not just a side remark, but was a word of dynamic power to be remembered and recorded, given by Jesus when he gave the first steps on this journey that would end with his ascension.

\section{Oral hermeneutics of the text}

The terms "oral mentality" and "oral frame of mind" have given rise to much misunderstanding but as we have established, the mere presence of literary activity does not invalidate or exclude the possibility of a profound oral texture in the texts. ${ }^{14}$

In all societies there is a holistic interaction and interdependence between the media of communication and social conventions. In view of our examination of Luke 9:51f. we now can note the broad outlines of how the pervasive oral texture in Luke corresponded with social conventions that modern readers find strange. ${ }^{15}$

\section{The efficacy of the word}

We have mentioned that Jesus' rebuke was a word of power as in the curse and blessing formulae in the Old and New Testaments. This corresponds with the dynamic and magical nature of the spoken word in oral cultures, a feature that was subsequently carried over to the written word.

\section{The concept of the corporate personality}

The dynamism of the word corresponds with conventions in oral cultures which deals differently with concepts such as solidarity and individuality than modern cultures. This also relates to the experience of words in oral cultures as being empathetic and participatory rather than expressions of individuality. This leads to a communal ethic in which matters are fundamentally open to negotiation; society is not rule-driven, but relationship-driven. We have noticed this as a presupposition in the relationship between rabbi and disciple. Luke's medium did not allow for an abstract treatise on the ethics of Jesus!

14. Halverson (1994) in a critique on Kelber (1983) is of the opinion that the widespread literacy in the ancient world defeats Kelber's oral theory. See also Botha (1997) for a discussion on the so-called "divide" between orality and literacy.

15. The following categories are adapted from Ong 1982a:31-77, from his chapter on "Some psychodynamics of orality". 


\section{The concept of (patriarchal) authority}

Oral theory also assists in understanding the authority of the rabbi which relates to what is commonly perceived as patriarchalism. In oral culture knowledge is difficult to attain and therefore precious. Thus the rebuke of Jesus has to be understood as an authoritative injunction by a figure or authority as constructed by its oral environment.

\section{A-historical time expression}

In primary oral cultures the concept of linear, abstract, chronological time is completely absent. Time is experienced in the same way as words are experienced: as something imminent and immediate. Time expressions attach an emotive value to the words of the speaker. Though the first century world has developed a sophisticated historical consciousness, time expressions still retained some of the force they have in primary oral environments. Thus the indication of the time in the above episode (when Jesus set his face to go to Jerusalem) is indicative of the actuality of the spoken word. We have already noted a trace of this in the disciples' echoing of a historical tradition, invoking Sodom and Gomorrah, as channelled through the Elijah tradition.

\section{An inevitable, passive, contextuality}

We have noted how the episode functions within the Lukan narrative, reflecting his context in a passive way. From an oral point of view it may be argued that repetitive modifications are naturally due to the inevitable contextual character of oral texts. Oral communication necessitates a direct contextual involvement of the speaker. The meaning of every word is thus controlled by the real-life situations of speaker and audience. In the process unnecessary information is continuously being deleted from memory, while points of interest to the audience are elaborated.

\section{Coherence located in the tradition}

Because oral texts work incessantly with repetitive contextual modifications it would be anachronistic to expect an abstract system of thought. It would be normal for modifications to occur within the same discourse as well in successive discourses. The coherence lies in the collective and communal tradition - which presupposes variant performances of the same material-rather than in a streamlined system. Each performance exhibits the character of a part of the whole. The written recording of such a performance would only be a mute witness of a much richer experience.

\section{Concrete and direct modes of expression}

Though Luke writes the most "literate" Greek of the evangelists his writing almost exclusively reflects this convention of oral communication. Instead of an abstract treatise on how to deal with rejection and enmity, the narrative presents the audience with a concrete narrative example. This correlates with the phenomenon that orality produces a sense of interiority, while literacy achieves the opposite. ${ }^{16}$ Oral performances produce an interior response by recreating a world of sound that delivers an experience that is percussive, populated with echoes, a world of voices, while the inter-relationships within the communicating community determine the effect that the sound has.

On the other side of the scale we find that a culture of writing promotes (though it does not determine) objectivity and linearity, implying a historical awareness and a more visual orientation in the world. Do we find something like this in Luke? Many scholars have depicted him as a historian with a linear and abstract time concept. Though we find some

16. See Ong 1982a:71f on the interiority of sound. 
degree of abstraction and historical awareness in Luke, this is still very far removed from a modern idea of linear time.

\section{Hermeneutical implications}

It may seem that our reading thus far has only extolled the virtues of oral poetics. However, once we have a reconstruction of the communication situation, we can gain a more critical distance on the message and begin to consider the hidden ideology of the medium.

Some critical aspects have been touched on already:

For Luke there was little if none opportunity for elaborating the literary intertext. This lack was later supplemented in the high manuscript culture by the addition of two clarifying glosses. The two scribal additions to the oldest Greek texts are clear indications of a thisboth intend to increase the literary intertextuality of the episode. This first explicitly links the saying of the disciples to Elijah (absent from p45 and p75, also from a, B) and the second to Jesus.

The oral style does not suit our mode of silent reading. This problem caused modifications in subsequent translations, introducing ever more variations in the text.

The context of the primary audience dominates the point of view and suppresses certain perspectives that we would have liked to elaborate. The vagueness about the Samaritans (see above), is a case in point. Luke's audience did not encourage an empathetic social and psychological view of the Samaritans. To Luke's audience of Roman nobility (Theophilus, c.s.) Samaria was obviously not high on the agenda; it was just a place of symbolic opposition with no direct relevance to the message of the pax christiana that Luke saw as the salvation of the world.

\section{A narrative ethic}

The question now remains whether a media critical reading can add anything to the interpretation of the passage. It should be obvious that such a reading does not favour any specific ethical interpretation. It rather leads the modern reader to open him/herself to the force of the oral narrative and to allow the oral intertext to happen. Such a procedure allows questions to multiply: Would Jesus, the Jew, today have travelled through the West bank, seeking to be received there by his Palestinian enemies? What would have happened? Should the violent anger of the oppressed always be met with Christian charity?

Most existing interpretations of the passage either follow deontological or consequentialist strategies. In Plummer's famous commentary, the passage is viewed deontologically as a lesson in tolerance: A missionary should not force himself on those who do not receive him. Thus it becomes a prescription for missionary strategy. ${ }^{17}$

An example of a consequentialist reading is found in The Matthew Henry Commentary. Here the focus is on a deliberation of the outcomes pursued:

“... Christ rebuked his disciples, because they envied for his sake. There, under the colour of zeal for Christ, they were for silencing and restraining separatists; here, under the same colour, they were for putting infidels to death; and, as for that, so for this also, Christ reprimanded them, for a spirit of bigotry and persecution is directly contrary to the spirit of Christ and Christianity." 18 
In summary, I hope to have demonstrated that a media critical reading is a plausible angle from which to approach the text. It helps us to enter a world where we can orientate ourselves within the hermeneutical co-ordinates of the Lukan audience, where the modern reader can experience something of the power of the oral (recited or performed) narrative. It recalls a narrative world in which such a reader can recoil at the rebuke of the Master when venting our anger on perceived enemies. Reading a text from a media critical point of view therefore not only seems to be a plausible method of entering a text, but also proves to be a necessary one. 


\section{BIBLIOGRAPHY}

Botha, PJJ 1997. Rethinking the oral-written divide in Gospel criticism: the Jesus traditions in the light of gossip research. Paper presented at the " $\mathrm{V}^{\text {th }}$ International Conference on Oral Tradition," 14-16 July 1997. The same material was presented under the title "Oral Tradition and its performance: beyond the verbal/non-verbal divide" at a seminar of the University of Natal, Durban, 1997-07-15.

Gerhardsson, B 1964. Tradition and transmission in early Christianity. Lund: Gleerup.

Gerhardsson, B 1990. "Oral tradition (New Testament)" in A dictionary of biblical interpretation, ed. by Coggins, RJ \& Houlden, JL. London: SCM Press.

Gerhardsson, B 1998. Memory and Manuscript: Oral tradition and written transmission in Rabbinical Judaism and early Christianity, with Tradition and transmission in early Christianity. Foreword by Jacob Neusner. Grand Rapids, Michigan: Eerdmans.

Halverson, J 1994. "Oral and written Gospel: A critique of Werner Kelber," New Test. Stud. 40: 180-195.

Havelock, EA 1963. Preface to Plato. Cambridge: Belknap of Harvard University.

Havelock, EA 1978. The Greek concept of justice: From its shadow in Homer to its subsistence in Plato. Cambridge, Mass.: Harvard University Press.

Havelock, EA 1984. “Oral composition in the 'Oedipus Tyrannus' of Sophocles," NLH 16. Pp 175-97.

Harvey, JD 1998. Listening to the text: Oral patterning in Paul's letters. Grand Rapids, Michigan: Baker Books.

Jousse, M 1990. The oral style, tr. by Sienaert, E et al. Garland Publishers: New York \& London.

Jousse, M 1997. The anthropology of geste and rhythm, studies in the anthropological laws of human expression and their application in the Galilean oral style tradition, (ed.) Sienaert, E and translated in collaboration with Conolly, J. Durban, South Africa: Centre for Oral Studies.

Kelber, WH 1983. The oral and the written Gospel, the hermeneutics of speaking and writing in the synoptic tradition, Mark Paul and Q. Philadelphia: Fortress.

Kelber, WH 1995. "Jesus and tradition: Words in time, words in space." Semeia 65 (1994), 139-167.

Loubser, JA 1986. "Die belang van die konteks in die lees van 'n teks", NGTT XXVII no 2, March 1986, 154-157.

Loubser, JA 1993. Orality and Pauline Christology: some hermeneutical implications, Scriptura 47, 25-51

Loubser, JA 1995. Orality and literacy in the Pauline corpus, some new hermeneutical implications. Neotestamentica 29 (1).

Loubser, JA 1996. Shembe preaching: a study in oral hermeneutics in African independent churches today, (ed.) Kitshoff, MC 1996. Lewiston, NY: Edwin Mellen Press.

McLuhan, M 1994. Understanding media: the extensions of man, introduction by Lewis $\mathrm{H}$ Lapham. Cambridge, Mass.: MIT Press

McLuhan, M 1999. The medium and the light: reflections on religion, edited by McLuhan, E and Szlarek J. Toronto: Stoddart.

Ong, WJ 1967. The presence of the Word. New Haven: Yale University Press. 
Ong, WJ 1977. Interfaces of the Word: studies in the evolution of consciousness and culture. Ithaca: Cornell University.

Ong, WJ 1982a. Orality and literacy, the technologizing of the word. London: Methuen.

Ong, WJ 1982b. "The oral and the written word: a reappraisal" in The literate revolution in Greece and its cultural consequences. Princeton: Princeton. Pp. 3-38.

Plummer, A 1975. The Gospel according to St. Luke. ICC. Edinburgh: T\&T Clark.

Robbins, VK 1995. Oral, rhetorical and literary cultures: A response. Semeia (1994) 65, 6594.

Robbins, Vernon K 1996. The tapestry of early Christian discourse: rhetoric, society and ideology. London and New York: Routledge.

Sellin, G and Vouga, F 1997. Logos und Buchstabe: Mündlichkeit und Schriftlichkeit in Judentum und Christentum der Antike. Tübingen and Basel: Francke Verlag.

Thomas, Rosalind 1992. Literacy and orality in ancient Greece. Cambridge: Cambridge University Press.

Vansina, J 1965. Oral tradition, a study in historical methodology, translated form French by Wright, HM. London: Routledge \& Kegan Paul.

Vansina, J 1985. Oral tradition, as history. Nairobi: Heinemann Kenya.

Winter, D (ed.) 1974. Matthew Henry's commentary, The four gospels. London: Hodder and Stoughton. 